\title{
THE INFLUENCE OF COMPETENCE, MOTIVATION AND ORGANIZATIONAL COMMITMENT TO THE PERFORMANCE OF FINANCIAL MANAGEMENT OF WORK UNIT GOVERNMENT DEVELOPMENT IN MINAHASA REGENCY
}

\author{
Yudith Pius Stevan Kaunang \\ Accounting Professional Education, Faculty of Economics and Business, Sam Ratulangi University, Jl. Kampus \\ Bahu, Manado, 95115, Indonesia \\ Email: hitachiyoudid@yahoo.co.id
}

\begin{abstract}
Government Regulation (or Peraturan Pemerintah-PP) Number 58 of year 2005 concerns Regional Financial Management and Regulation of the Minister of Home Affairs (or Permendagri) Number 13 of 2006 concerning Regional Financial Management Guidelines as amended several times, most recently by Permendagri Number 21 of 2011 it is stated that regional finance is managed in an orderly manner, obeying the laws and regulations, efficiently, economically, effectively, transparently, and responsibly by paying attention to the principles of justice, propriety, and benefits to society.Financial management in the regions requires a reliable application, which is an application that can process data (input) and produce information (output) to assist management in making decisions, and can produce financial reports and other financial information more comprehensively, includes information about the regional financial position, financial performance conditions, and accountability of local governments. In term to optimize the performance of regional financial management, the Financial and Development Supervisory Agency (or Badan Pengawasan Keuangan dan Pembangunan) has responded positively through the development of a financial SIMDA application program. This SIMDA financial application has been integrated starting from the budgeting function, regional financial administration functions, to the accounting and reporting functions. The type of data used in this study is, Qualitative Data is data obtained from the technique of gathering through a Questionnaire.This data collection was carried out on 48 Regional Work Units in the Minahasa Regency. The results of this study indicate that competency, motivation and organizational commitment have a significantly positive and partially significant impact on performance of financial management.
\end{abstract}

Keywords: competence; motivation; organizational commitment; regional work unit; SIMDA JEL Classification : H11,H83

Article info:

Received 3 March 2020

Revised 3 March 2020

Accepted 3 March 2020

Available online 3 March 2020

\section{INTRODUCTION}

In managing finances in an orderly, obedient to the laws and regulations, efficient, economical, effective, transparent, and responsible, financial managers must have good performance as well. Safwan (2014) states that performance is a picture of the level of achievement of the implementation of a program and activities to realize the vision, mission, goals and objectives of the organization as outlined in strategic planning. Without goals and targets, the performance of a person or organization might not be known because there are no benchmarks. 
In condition to improve performance of Local Government Agencies (or Satuan Kerja Perangkat Daerah-SKPD) financial management, many factors need to be considered, such as competency, motivation, and organizational commitment. Safwan et al. (2014) states competence is the knowledge and skills as well as the ability of a person to perform cognitive, effective and psychomotor behaviors by truly applying them in accordance with established performance standards.Competence affects employee performance which means higher competency possessed by employees in accordance with the tasks they carry then it will always encourage employees to work effectively, efficiently and productively.Employees who have good competence will be able to carry out their duties properly so that financial management performance will increase (Safwan et al., 2014).

Motivation is also a factor influencing the performance of SKPD financial management. Motivation is something in a person who strongly encourages the desire to carry out work seriously in order to achieve goals and objectives.Some regions make policies to encourage employees to work more optimally, such as by providing incentives in the form of work performance benefits and overtime pay (Safwan et al., 2014). The phenomenon that has existed so far, although motivation is often given, it has not been effective enough to motivate employees to improve their performance. Another factor influencing the performance of SKPD financial management is organizational commitment. Employees with high commitment can be expected to show optimal performance. Rachmawati (2008) mentions organizational commitment is an attitude that shows employee loyalty and is an ongoing process of how an organization member expresses their attention to the success and goodness of the organization.

Financial management in the regions requires a reliable application, which is an application that can process data (input) and produce information (output) to assist management in making decisions, and can produce financial reports and other financial information more comprehensively, includes information about the regional financial position, financial performance conditions, and accountability of local governments.To optimize the performance of regional financial management, the Financial and Development Supervisory Agency (or Badan Pengawasan Keuangan dan Pembangunan-BPKP) has responded positively through the development of a management information system for local government (or Sistem Informasi Manajemen Daerah-SIMDA). This SIMDA financial application has been integrated starting from the budgeting function, regional financial administration functions, to the accounting and reporting functions (BPKP, 2016).

\section{LITERATURE REVIEWS}

In Permendagri Number 13 of year 2006 concerning Guidelines for Regional Financial Management and Government Regulation(or Peraturan Pemerintah-PP) Number 58 of year 2005 concerning Regional Financial Management article 1 paragraph 6 explained that what is meant by regional financial management is the whole activity which includes planning, implementation, administration, reporting, accountability, and supervision of regional finances. Callahan (2006) defines that performance as to how far the organization achieves results when compared to the previous organization (previous performance), compared to the achievements of other organizations (benchmarking), and to what extent the achievement of goals and targets has been set. On those definitions, it can be concluded that the SKPD financial management performance is the result of quality and quantity of work achieved by employees in carrying out the duties and responsibilities given from carrying out the required functions and constitutes an act, achievement, and skills that are basically is what employees do or don't do so that goals and objectives can be realized.SIMDA implementation is an application program used for regional financial management that is integrated and fast, 
accurate and efficient in producing financial information that will be used for decision making in various matters in the government sector (BPKP, 2016).

Wibowo (2007:272) states that competence is defined as the ability to carry out or perform a job or task based on the skills and work knowledge required by the job. Thus, competence shows the skills or knowledge that are characterized by professionalism in a particular field as the most important. Competence as a characteristic of a person is related to effective performance in a job or situation. Moeheriono (2009:3) also states that competence is an underlying characteristic of a person related to performance effectiveness individuals in their work or basic characteristics of individuals who have a relationship causal or as a cause and effect with criteria that are used as reference, effective or excellent or superior performance at work or in certain situations.

Sedarmayanti (2009) states that motivation is a source of encouragement that causes someone to do something that leads to the achievement of needs, provide satisfaction, or reduce imbalances. Hasibuan (2007) states that work motivation is a willingness to strive optimally in achieving organizational goals that are influenced by the ability of businesses to satisfy the needs of some individuals. Uno (2007) also states that motivation can be interpreted as internal and external impulses in a person as indicated by the existence of desires and interests; encouragement and needs; hopes and ideals; appreciation and respect.

Ikhsan and Ishak (2008) states that organizational commitment is the extent to which employees favor a certain organization that aims to maintain membership in the organization. High individual commitment makes individuals more concerned with the organization than personal interests and try to bring the organization to be better. Low organizational commitment will make individuals do their personal interests. Organizational commitment grows when each individual develops interrelated attitudes towards the organization andor profession. These attitudes include identification (identification), namely understanding or appreciation of organizational goals, involvement (involvement), namely the feeling of being involved in a job or the feeling that the work is fun, loyalty (loyalty), namely the feeling that the organization is the place to work and live (Ikhsan and Ishak, 2008).

\section{RESEARCH METHOD}

This research is associative research (causal associative effect)which means search relationship of some uncertain variables. Umar (2008:38) states that causal associative design is useful for analyzing how a variable influences other variables and it is also useful for researchers who are experimental in that the independent variable is treated in a controlled manner to see its impact on the dependent variable directly. The study is designed to analyze the direct effect of variables of competency, motivation, and organizational commitment (commitment) on the SKPD financial management performance (performance) variables in the Minahasa District Government. The equation of this study noted as follow:

$$
\mathrm{Y}=\mathrm{b}_{1} \mathrm{X}_{1}+\mathrm{b}_{2} \mathrm{X}_{2}+\mathrm{b}_{3} \mathrm{X}_{3}+\varepsilon_{1}
$$

$\mathrm{Y}$ is performance, $\mathrm{X}_{1}$ is competency, $\mathrm{X}_{2}$ is motivation, and $\mathrm{X}_{3}$ is commitment. The population of this study is the Budget Users (or Pengguna Anggaran-PA) or Proxy of Budget User (or Kuasa Pengguna Anggaran-KPA), Executive Officer of Technical Action (or Pejabat Pelaksana Teknis Kegiatan-PPTK), and Commitment Making Official (or Pejabat Pembuat Komitmen-PPK) of 48 SKPD Minahasa District Government consisting of 2 secretaries, 7 agencies, 16 offices, 8 offices and 15 districts. The total population of this study is 150 respondents. The sampling method is the census method, where all members of the study population are used as respondents so that the number of samples of this study is the same as the population.

This study uses primary data at the research location. Primary data is data collected directly from the object under study using a research instrument in the form of a 
questionnaire. Source of data used in this study is qualitative data in the form of primary data obtained directly in accordance with the original (not through intermediary media). Umar (2008:38) states that primary data is data obtained from the first source, namely from individuals or individuals through interviews or filling out questionnaires that are normally carried out by researchers.

The questionnaire for data collection will be delivered by the researcher himself and waited for 14 days, then picked up directly by the researcher. The variables to be studied are limited to 4 (four) factors which are estimated to influence the performance of SKPD financial management, namely competency, motivation, and organizational commitment, plus the implementation of financial SIMDA as an intervening variable.

\section{RESULT AND DISCUSSIONS}

\subsection{Result}

The data collection in this study carried out in 1 phase namely by giving 150 questionnaires to respondents covering 48 SKPD in Minahasa Regency, which consisted of 7 agencies, 16 offices, 1 inspectorate, and 22 offices, 2 secretaries. Then, according to the allotted time, the questionnaire was picked up again. On 150 questionnaires sent/distributed the 135 is returned. Table 1 presents results of the returned questionnaire obtained an overview of the research variables.

Table1. Descriptive statistics

\begin{tabular}{lcrrrr}
\hline & N & Minimum & Maximum & Mean & Std. Deviation \\
\hline Performance & 135 & 19,00 & 30,00 & 25,22 & 2,25 \\
Competency & 135 & 19,00 & 30,00 & 24,51 & 2,12 \\
Motivation & 135 & 17,00 & 30,00 & 24,43 & 2,15 \\
Commitment & 135 & 18,00 & 30,00 & 24,25 & 2,36 \\
Valid N (listwise) & 135 & & & & \\
\hline
\end{tabular}

According to Ghozali (2013), data shall be called reliable if the value of Cronbach Alpha is more than 0.70 and should be valid by its correlation. Table 2 presents the results of reliability and validity test of this study.

Table 2. Validity and reliability test

\begin{tabular}{ccccc}
\hline & Performance $(\mathbf{Y})$ & Competency $\left(\mathbf{X}_{\mathbf{1}}\right)$ & Motivation $\left(\mathbf{X}_{\mathbf{2}}\right)$ & Commitment $\left(\mathbf{X}_{\mathbf{3}}\right)$ \\
\hline Question 1 & $0,473^{*}$ & $0,297^{*}$ & $0,430^{*}$ & $0,581^{*}$ \\
Question 2 & $0,363^{*}$ & $0,469^{*}$ & $0,473^{*}$ & $0,477^{*}$ \\
Question 3 & $0,467^{*}$ & $0,550^{*}$ & $0,687^{*}$ & $0,395^{*}$ \\
Question 4 & $0,467^{*}$ & $0,358^{*}$ & $0,352^{*}$ & $0,468^{*}$ \\
Question 5 & $0,486^{*}$ & $0,434^{*}$ & $0,457^{*}$ & $0,601^{*}$ \\
Question 6 & $0,598^{*}$ & $0,518^{*}$ & $0,624^{*}$ & $0,403^{*}$ \\
Cronbach Alpha & 0.728 & 0.702 & 0.751 & 0.742 \\
\hline
\end{tabular}

*is significant

Based on the equations of this study, Table 3 presents the result of analysis.

Table 3. Regression results

\begin{tabular}{lr}
\hline \multicolumn{1}{c}{ Variables } & Dependent: Performance \\
\hline Constant & 1.757 \\
Competence & $0.448^{* * *}$ \\
Motivation & $0.272^{* * *}$ \\
Commitment & $0,241^{* * *}$ \\
\hline$* * *, * *, *$ indicate significance on $1 \%, 5 \%$, and $10 \%$ & \\
\hline
\end{tabular}


The constant value factor is 1.757 , meaning that if all independent variables namely competence, motivation and organizational commitment are assumed to be zero, then the value of the performance of financial management is 1.757. Competency regression coefficient of 0.448 , meaning that partially competence (X1) has a positive and significant effect (tig $0.009<\alpha$ tolerance 0.05 ) on the performance of SKPD financial management (Y2). Thus, it can be concluded that if competency increases by 1 unit, the performance of SKPD financial management will increase by 0.448 assuming all other independent variables are zero. This is in line with Safwan et al. (2014), Rafar et al. (2015), and Ronal et al. (2018), which concluded that competence has a significant effect on the performance of regional financial management. Motivational regression coefficient (X2) of 0.272 means that partially motivation has a positive and significant effect (tig $0.001<\alpha$ tolerance 0.05 ) on the performance of SKPD financial management (Y2). Thus, it is concluded that if motivation increases by 1 unit, the performance of SKPD financial management will increase by 0.272 . This is in line with Safwan et al. (2014) which concluded that motivation influences the performance of regional financial management and Bahairi (2011) concludes that motivation influences the performance of PPK SKPD.

Regression coefficient of organizational commitment (X3) of 0.241 , meaning that partially organizational commitment has a positive and significant effect (tig $0,000<\alpha$ tolerance 0.05) on the performance of SKPD financial management (Y2). Thus, it can be concluded that if motivation increases by 1 unit, the performance of SKPD financial management will increase by 0.272. This is in line with Kalilago and Saleh (2012) which concluded that organizational commitment significantly influences the performance of SKPD and Anandhika (2011) which concludes organizational commitment, significantly influences the performance of regional financial management. This condition means that competency (X1), motivation (X2) and organizational commitment (X3) show a direct or positive relationship with the performance of SKPD financial management (Y2) that any increase in competency, motivation and organizational commitment will cause an increase in SKPD financial management performance. Of the 3 variables used as predictors of the performance of SKPD financial management, the competency variable was identified as the strongest variable affecting the performance of SKPD financial management.

\subsection{Discussions}

Based on the results of the F test on the first hypothesis testing, it can be concluded that together competency, motivation, and organizational commitment have a significant positive effect on the performance of SKPD financial management. Based on the test on the first hypothesis testing it can be concluded, that partially competence, motivation and organizational commitment have a significant positive effect on the performance of SKPD financial management.

Effect of competence on the performance of SKPD financial management. Competence is a skill, knowledge, basic attitude and values that are reflected in the habits of thinking and acting that are developing, dynamic, continuous (continuous) and can be achieved at any time. The habit of thinking and acting constantly, consistently and continuously will make someone competent. The more competent an employee is, the better the financial management performance of the SKPD where the employee works. Testing the effect of the competency variable on the SKPD financial management performance variable used the $t$ test and the results of the significance level of the competency variable are smaller than alpha tolerance. It shows that competency has a significant positive effect on the SKPD financial management performance variable. Based on the frequency distribution of competencies (Appendix 6) shows an average value above 4. It shows competency can have a positive influence on the performance of SKPD financial management, so that financial management in the Minahasa Regency is increasing in opinion. This is in line with Safwan et 
al. (2014) which concluded that partially, competence has a significant effect on the performance of regional financial management and Rena (2012) also concluded partially, competence has an effect on the performance of financial managers.

The influence of motivation on the performance of SKPD financial management. Motivation is something in a person who strongly encourages the desire to carry out the work seriously to achieve goals and objectives. Motivation is often in the form of incentives given to employees to improve their performance. High motivation owned by individual employees can improve financial management performance in each SKPD. The better the motivation of an employee, the better the performance of the employee especially in SKPD financial management. Based on the frequency distribution of motivation (Appendix 6) shows an average value above 4 . It shows that motivation can have a positive influence on the performance of SKPD financial management. This was indicated by the better opinion on the financial statements obtained by the Government of the Minahasa Regency. The results of statistical analysis show that partially, motivation has a significant positive effect on the performance of SKPD financial management, where the level of significance of motivation variables is smaller than alpha tolerance. This is in line with research Safwan et al. (2014) concluded that motivation influences the performance of regional financial management and Bahairi (2011) also concluded that motivation affects the performance of PPK SKPD.

Effect of organizational commitment on the performance of SKPD financial management. Organizational commitment is an attitude that shows employee loyalty and is an ongoing process of how an employee expresses their attention to the success and goodness of the organization (Rachmawati, 2008). A good understanding of the organization's vision and mission encourages each member of the organization to have high commitment in order to improve performance SKPD financial management. A clear understanding of the organization's vision and mission is an indicator of fulfilling organizational commitment that has a positive impact on all planning in the organization. The frequency distribution of organizational commitment states that the average value is above 4. It states that organizational commitment is able to have a positive influence on the performance of SKPD financial management. Based on statistical results, partially organizational commitment has a significant positive effect on the performance of SKPD financial management, with a significance level less than $\alpha$. With catalyst, the more organizational employee commitment in an SKPD increases, the more financial management performance in the SKPD increases. This is in line with Kalilago and Saleh (2012) which concluded that organizational commitment significantly influences the performance of SKPD and Anandhika (2011) also concludes organizational commitment, significantly influences the performance of regional financial management.

\section{CONCLUSION}

This study concludes that competency, motivation, and organizational commitment have a significant positive effect on the performance of SKPD financial management in the Minahasa Regency Government. This study suggests that for further researchers it is recommended, in addition to applying the survey method through questionnaires to conduct direct interviews to avoid misperceptions and obtain better information, so that the data obtained can better explain the actual situation. The Government of the Minahasa Regency should continue to improve competence, motivation, organizational commitment and SIMDA implementation to the SKPD apparatus especially in the SKPD financial management. The further researchers who want to examine the factors that influence the performance of SKPD financial management in order to add other variables such as education and training, and compliance with laws and regulations. 


\section{REFERENCES}

Anandhika, A. M. (2011). Pengaruh motivasi kerja dan komitmen organisasi terhadap kinerja pegawai bidang keuangan pada pemerintah daerah Kabupaten Demak. Skripsi. http://eprints.undip.ac.id/29311/1/.

Badan Pengawasan Keuangan dan Pembangunan. (2016). Pengenalan Sistem Informasi Manajemen Daerah (SIMDA) Keuangan, http://www.bpkp.go.id/sakd/konten/333/Versi-2.1.bpkp

Bahairi. (2011). Faktor-faktor yang mempengaruhi kinerja Pejabat Penatausahaan Keuangan Satuan Kerja Perangkat Daerah (PPK-SKPD) di lingkungan Pemerintahan Provinsi Kepulauan Bangka Belitung. Skripsi. http://repository.ut.ac.id/1753/

Callahan, K. (2006). Elements of effective governance: Measurement, accountability and participation. New York: Routledge, Taylor \& Francis Group. https://doi.org/10.1201/9781420013429

Ghozali, H. I. (2013). Aplikasi analisis multivariate dengan Program IBM SPSS 21, Cetakan VII. Semarang: Badan Penerbit Universitas Diponegoro.

Hasibuan, M. S. P. (2007). Manajemen sumber daya manusia, Edisi Revisi. Jakarta: Bumi Aksara.

Ikhsan, A., \& Ishak, M. (2008). Akuntansi keperilakuan. Jakarta: Salemba Empat.

Kalilago, O., \& Saleh, S. (2012). Faktor-faktor yang mempengaruhi kinerja Satuan Kerja Perangkat Daerah terhadap pengelolaan keuangan daerah pada Pemerintahan Kabupaten Sorong Selatan tahun 2011. Tesis. http://etd.repository.ugm.ac.id/home/detail_pencarian/55968.

Moeheriono. (2009). Pengukuran kinerja berbasis kompetensi. Depok: Rajawali Pers.

Rachmawati, I. K. (2008). Manajemen sumber daya manusia, Edisi 1. Yogyakarta: Andi.

Rafar, T. M., Fahlevi, H., \& Basri, H. (2015). Pengaruh kompetensi pengelola keuangan dan akuntabilitas terhadap kinerja pengelolaan keuangan daerah (Studi pada Satuan Kerja Perangkat Daerah Pemerintah Kabupaten Aceh Utara). Jurnal Administrasi Akuntansi: Program Pasca Sarjana Unsyiah, 4(2), 64-71. http://www.jurnal.unsyiah.ac.id/JAA/article/view/4469

Ronal, T., Wawo, A. B., \& Rosnawintang. (2018). Pengaruh kompetensi dan motivasi terhadap kinerja pengelola keuangan pada Satuan Kerja Perangkat Daerah (SKPD) lingkup pemerintah Provinsi Sulawesi Tenggara. Jurnal Progres Ekonomi Pembangunan, 3(2), 1-14. http://dx.doi.org/10.33772/jpep.v3i2.8003.

Safwan, Nadirsyah, \& Abdullah, S. (2014). Pengaruh kompetensi dan motivasi terhadap kinerja pengelolaan keuangan daerah pada Pemerintah Daerah Kabupaten Pidie Jaya. Jurnal Akuntansi Program Pascasarjana Universitas Syiah Kuala, 3(1), 133-139. https://www.researchgate.net/publication/304423255_PENGARUH_KOMPETENSI_ DAN_MOTIVASI_TERHADAP_KINERJA_PENGELOLAAN_KEUANGAN_DA ERAH_PADA_PEMERINTAH_DAERAH_KABUPATEN_PIDIE_JAYA

Sedarmayanti. (2009). Sumber daya manusia dan produktivitas kerja. Bandung: Mandar Maju.

Umar, H. (2008). Metode penelitian untuk skripsi dan tesis bisnis. Jakarta: Rajawali Pers.

Uno, H. B. (2007). Teori motivasi dan pengukurannya: Analisis di bidang pendidikan. Jakarta: Bumi Aksara.

Wibowo. (2007). Manajemen kinerja. Jakarta: PT. Raja Grafindo Persada. 